\title{
Meningkatkan Kemampuan Koneksi Matematik dan Self Efficacy Mahasiswa melalui Model CORE
}

\author{
Tri Arif Wiharso ${ }^{*}$ dan Helfy Susilawati ${ }^{2}$ \\ ${ }^{1 *}$ Teknik Telekomunikasi FTEK, Universitas Garut \\ Cempaka Indah blok 7 No 75, Garut, jawa barat, Indonesia \\ 1*triarif@uniga.ac.id \\ 2Teknik Elektro FTEK, Universitas Garut \\ Kp. Sukamentri, Garut, jawa barat, Indonesia \\ 2helfy.susilawati@uniga.ac.id
}

Artikel diterima: 22-09-2019, direvisi: 26-09-2020, diterbitkan: 30-09-2020

\begin{abstract}
Abstrak
Penelitian ini bermaksud untuk memperoleh hasil peningkatan kemampuan Koneksi matematik dan self efficacy melalui pembelajaran Model CORE, selain itu untuk melihat respon mahasiswa terhadap belajar matematik dengan model CORE. Pelaksanaan penelitian ini berbentuk quasi eksperimen dengan membandingkan prestasi belajar mahasiswa melalui model CORE dengan mahasiswa yang memperoleh pembelajaran konvensional. Populasi berasal dari mahasiswa Fakultas Teknik di Perguruan Tinggi di Garut dengan sampel penelitiannya berjumlah 54 mahasiswa. Dengan 27 orang diberi pembelajaran dengan model CORE dan 27 lainnya melalui pembelajaran konvensional. Dalam pengambilan data digunakan Instrumen berupa tes matematik, angket model CORE dan angket self efficacy. Hasil yang didapat yaitu: 1) Peningkatan Koneksi matematik mahasiswa yang mendapatkan pembelajaran dengan model CORE lebih baik dari pada mahasiswa yang memperoleh pembelajaran konvensional. 2) Self efficacy mahasiswa yang mendapatkan pembelajaran dengan model CORE peningkatannya tidak lebih baik dari pada mahasiswa yang memperoleh pembelajaran konvensional. 3) Terdapat hubungan antara model CORE dengan Self efficacy dalam kategori sedang. 4) Mahasiswa memberikan kesan yang positif terhadap model CORE.

Kata kunci: Model CORE, Koneksi Matematik, Self efficacy.
\end{abstract}

\section{Improving Mathematical Connection Ability and Self Efficacy Students through Core-Based Models}

\begin{abstract}
This study aims to obtain the results of increasing the ability of mathematical connections and selfefficacy through learning the CORE Model, in addition to seeing student responses to learning mathematics with the CORE model. The implementation of this research is in the form of a quasiexperiment by comparing student learning achievement through the CORE model with students who receive conventional learning. The population came from students of the Faculty of Engineering at Higher Education in Garut with a research sample of 54 students. With 27 people being taught using the CORE model and 27 others through conventional learning. In collecting the data, instruments were used in the form of a mathematical test, a CORE model questionnaire, and a self-efficacy questionnaire. The results obtained are: 1) Increased mathematical connection of students who get learning with the CORE model is better than students who receive conventional learning. 2) The increase in self-efficacy of students who get learning with the CORE model is not better than students who get conventional learning. 3) There is a relationship between the CORE model and Self-efficacy in the medium category. 4) Students give a positive impression on the CORE model.

Keywords: CORE Model, Mathematical Connection, Self-efficacy.
\end{abstract}




\section{Pendahuluan}

Kemampuan koneksi perlu dimiliki oleh siswa dalam mempelajari matematika pada setiap tingkatan sekolah dan perguruan tinggi (Pitriani \& Afriansyah, 2017; Lubis, Harahap, \& Nasution, 2019). Semisal di fakultas teknik dimana matematika menjadikan matakuliah wajib yang harus dikuasai oleh mahasiswa dikarenakan hampir semua matakuliah di fakultas teknik memerlukan konsep dasar matematika dan mereka tentunya harus dapat menghubungkan keterkaitan terhadap konsep lainnya terutama dalam bidang keteknikan. seperti keterkaitan terhadap matakuliah fisika, Rangkaian listrik, sistem kontrol dan sebagainya.

Keterkaitan konsep dalam matematika bisa dilihat dari materi-materi yang dipelajari selama ini dalam pelajaran matematika (Afriansyah, 2012; Sapilin, Adisantoso, \& Taufik, 2019) misalnya untuk mempelajari persamaan diferensial harus mempelajari dahulu konsep turunan dan integral. Dimana kalau dihubungkan dengan bidang lain seperti pada rangkaian listrik persamaan diferensial dipakai untuk mencari besar arus listrik pada rangkaian listrik RL seri atau bisa juga untuk mencari besar muatan pada rangkaian listrik RLC seri. Sejalan dengan pernyataan sebelumnya, teori yang mendukung pentingnya kemampuan koneksi matematik. Menurut NCTM (2000; Asih \& Ramdhani, 2019) terdapat 5 kemampuan dasar matematik yang perlu dikuasai yaitu komunikasi (communication), pemecahan masalah (problem solving), koneksi (connections) penalaran dan pembuktian (reasoning and proof), dan representasi (representation).

Dikarenakan pentingnya kemampuan koneksi matematik (Mayasari \& Afriansyah, 2016) maka mahasiswa harus memperlihatkan penguasaan mereka. Dari hasil wawancara penulis dengan beberapa dosen fakultas teknik di Garut, khususnya yang berkaitan dengan matakuliah matematika memberitahukan bahwa mahasiswa masih kesulitan dalam mengaitkan konsep matematika dengan matakuliahnya seperti misalnya dalam menerapkan konsep matematika kedalam teori fisika listrik, rangkaian listrik, membuat model matematik dari suatu permasalahan dan konsep lainnya.

Selain kemampuan koneksi matematik mahasiswa juga memerlukan self efficacy (Moma, 2014). Menurut Bandura (1997) self efficacy merupakan keyakinan seorang individu mengenai kemampuannya dalam mengorganisasi dan menyelesaikan suatu tugas yang diperlukan untuk mencapai hasil tertentu. Self Efficacy juga merupakan aspek yang dapat mempengaruhi kinerja seseorang untuk meraih suatu tujuan (Robbins, 2003; Mujib, 2017). Dengan demikian dapat dikatakan memiliki Self Efficacy yang baik membuat mahasiswa dapat menyelesaikan permasalahan dalam matematika baik yang berhubungan dengan konsep dalam matematika maupun diluar bidang matematika. 
Selanjutnya, untuk menumbuh memperluas, menggunakan dan kembangkan kemampuan koneksi menemukan. Dengan pembelajaran seperti matematik dan self efficacy diperlukan ini memungkinkan siswa dapat pendekatan pembelajaran yang dapat meningkatkan kemampuan koneksi membuat siswa aktif, tidak cemas, matematiknya serta karena pembelajaran menyenangkan selama pembelajaran ini berorientasi pada diskusi dalam terjadi interaksi baik sesama siswa maupun dengan pengajar serta dapat mengkonstruk pengetahuan yang didapatnya dengan pengetahuan yang baru dalam menyelesaikan permasalahan matematik (Alexandra \& Ratu, 2018). Dengan demikian, diperlukan model pembelajaran yang memungkinkan semua itu terjadi, seperti model CORE (Connecting, Organizing, Reflectin and Extending).

Bandura (1997) mendefinisikan self efficacy sebagai keyakinan seorang individu mengenai kemampuannya dalam mengorganisasi dan menyelesaikan suatu tugas agar tercapainya suatu hasil. Dari pengertian tersebut bila dihubungkan dengan keyakinan diri siswa dalam menyelesaikan persoalan dalam matematika tentunya akan berpengaruh terhadap hasil belajar dari siswa tersebut (Dewi \& Afriansyah, 2018). Oleh karena itu, siswa harus mempunyai self efficacy atau keyakinan yang tinggi.

Model CORE (Connecting, Organizing, Reflectin and Extending) menurut Ngalimun (2014) adalah (C) koneksi informasi lama-baru dan antar konsep, (O) organisasi ide untuk memahami materi. (R) memikirkan kembali, mendalami, dan menggali, (E) mengembangkan, kelompok menjadikan siswa bisa lebih yakin dengan penyelesaian masalah matematik yang dikerjakannya karena bisa saling berinteraksi dengan temannya sehingga memperkuat self efficacy.

Sintak model pembelajaran CORE menurut Suyatno (Nur Fallah, 2017) yaitu: 1) Tahap connecting, penghubungan pengetahuan baru dengan pengetahuan lama; 2) Tahap organizing, siswa mengambil kembali ide-ide mereka; 3) Tahap reflecting, adanya bimbingan guru dalam kekeliruan yang dilakukan siswa dalam hal mengkoordinasikan pengetahuannya; dan 4) Tahap extending, pada tahap ni siswa dapat memperlihatkan kemampuan hasil belajar mereka terhadap permasalahan baru.

\section{Metode}

Jenis penelitian yaitu kuasi eksperimen dengan bentuk Nov Equivalent Control Group Design. Dalam bentuk penelitian ini, subjek tidak dikelompokkan secara acak murni tetapi peneliti menerima keadaan subjek seadanya (Ruseffendi, 2010). Atau sering disebut pretes dan postes group design. Dengan rancangan penelitian seperti pada table 1 berikut. 
Tabel 1.

Rancangan Penelitian

\begin{tabular}{|l|l|l|}
\hline$O_{1}$ & $X_{1}$ & $O_{2}$ \\
\hline$O_{1}$ & $X_{2}$ & $O_{2}$ \\
\hline
\end{tabular}

Sumber : Ruseffendi, 2010

Keterangan :

$O_{1}=$ Tes awal

$\mathrm{O}_{2}=$ Tes akhir

$X_{1}=$ Pembelajaran metode CORE

$X_{2}=$ Pembelajaran konvensional.

Dengan populasi seluruh mahasiswa Fakultas Teknik semester II di Perguruan Tinggi di Garut tahun, akademik 2018/2019. Pemilihan populasi di Fakultas teknik dikarenakan konsep matematika banyak berhubungan dengan mata kuliah lainnya yang cocok dengan topik penelitian. Dalam menentukan sampel dilakukan dengan cara acak, sehingga didapat untuk kelas kontrol yaitu kelas $A$ dan untuk kelas eksperimen yaitu kelas B. Pemilihan sampel dengan memepertimbangkan bahwa kemampuan mahasiswa fakultas teknik tiap kelas mempunyai kemampuan yang sama.

Analisis data untuk peningkatan koneksi matematik didapat dari instrumen penelitian berbentuk soal isian sebanyak 5 soal dengan indikator mahasiswa dapat menyelesaikan solusi PDB orde satu, mahasiswa dapat menyelesaikan solusi $P D B$ orde dua, mahasiswa dapat menyelesaikan solusi $P D B$ orde $n$, mahasiswa dapat menyelesaikan permasalahan $P D B$ dengan konsep rangkaian Listrik. Contoh sebagian soal untuk mengukur pengaruh terhadap hasil belajar mahasiswa, seperti pada tabel 2 berikut.

Tabel 2.

Contoh instrumen penelitian

\begin{tabular}{|c|c|}
\hline No & Soal \\
\hline 2 & $\begin{array}{l}\text { Carilah solusi dari persamaan } \\
\text { diferensial } \\
\frac{d^{3} y}{d x^{3}}-3 \frac{d^{2} y}{d x^{2}}+2 \frac{d y}{d x}=0\end{array}$ \\
\hline 3 & $\begin{array}{l}\text { Dapatkan solusi persamaan } \\
\text { diferensial dari } \frac{d^{2} y}{d x^{2}}+6 \frac{d y}{d x}-16 y= \\
9 e^{x}\end{array}$ \\
\hline 5 & $\begin{array}{l}\text { Sebuah rangkaian } R L C \text { seri dengan } \\
\text { resistansi } R=200 \text { ohm, induktansi } L \\
=100 \text { Henry, kapasitansi } C=0,01 \\
\text { Farad dan suatu sumber tegangan } \\
\text { konstan sebesar } 6000 \text { volt. Tentukan } \\
\text { muatannya saat t. }\end{array}$ \\
\hline
\end{tabular}

Selanjutnya untuk mendapatkan data peningkatan self efficacy dilakukan dengan cara memberikan angket kepada mahasiswa setelah diberikan perlakuan kepada kedua kelas yaitu kelas eksperimen dan kelas kontrol. Dengan indikator soal angket terdapat pada tabel berikut :

Tabel 3.

Indikator angket self efficacy

\section{No Sikap Siswa Indikator}

\begin{tabular}{|lll|}
\hline 1 & Magnitude & $\begin{array}{l}\text { Keyakinan terhadap } \\
\text { sesuatu yang belum } \\
\text { dicoba }\end{array}$ \\
\cline { 3 - 3 } & & $\begin{array}{l}\text { Menghadapi tugas yang } \\
\text { sulit }\end{array}$ \\
\hline 2 & Generality & $\begin{array}{l}\text { Konsisten pada tugas } \\
\text { Kesiapan terhadap situasi }\end{array}$ \\
\hline 3 & Strengh & \begin{tabular}{l} 
Ketahanan dan kegigihan \\
dalam menghadapi tugas \\
\cline { 3 - 3 }
\end{tabular} \\
& $\begin{array}{l}\text { Keberhasilan pengalaman } \\
\text { sebelumnya }\end{array}$ \\
\hline
\end{tabular}


Contoh sebagian soal angket untuk mengukur self efficacy mahasiswa terdapat pada tabel 3 berikut.

Tabel 3.

Contoh instrumen penelitian

\begin{tabular}{|lll|}
\hline No & Pernyataan & \multicolumn{1}{c}{ Jawaban } \\
\cline { 3 - 3 } & $\begin{array}{l}\text { Saya yakin dapat memahami materi matematika yang diberikan } \\
\text { dosen }\end{array}$ & \\
\hline 2 & $\begin{array}{l}\text { Saya yakin dapat menyelesaikan masalah matematika yang } \\
\text { diberikan dosen walapun rumit }\end{array}$ \\
\hline 3 & $\begin{array}{l}\text { Dalam pembelajaran kelompok saya bisa berkontribusi dalam } \\
\text { memecahkan masalah matematika }\end{array}$ \\
\hline 11 & $\begin{array}{l}\text { Saya mampu menyelesaikan sendiri soal matematika saat ujian } \\
\end{array}$
\end{tabular}

\section{Hasil dan Pembahasan}

Penelitian ini menghasilkan data dari tes awal, tes akhir dan angket. Datanya didapat dari kelas eksperimen yang menggunakan model CORE dan kelas kontrol yang menggunakan pembelajaran konvensional. Hasil perhitunga datanya tersaji pada tabel 4 berikut.

Tabel 4.

Rekapitulasi Hasil Tes Kemampuan Koneksi Matematika

\begin{tabular}{|c|c|c|c|c|c|c|}
\hline & & & Eksperime & & Kontrol & \\
\hline & \multicolumn{2}{|l|}{ Skor Ideal } & Tes Awal & Tes Akhir & Tes Awal & Tes Akhir \\
\hline \multirow{6}{*}{$\begin{array}{l}\text { Koneksi } \\
\text { Matematika }\end{array}$} & \multirow{6}{*}{100} & $\mathrm{~N}$ & 27 & & & \\
\hline & & Mean & 19,44 & 70 & 19,63 & 59,63 \\
\hline & & $\%$ & 19,44 & 70 & 19,63 & 59,63 \\
\hline & & St. Dev & 9,64 & 11,18 & 9,19 & 12,85 \\
\hline & & Min & 5 & 45 & 5 & 35 \\
\hline & & Max & 45 & 90 & 40 & 85 \\
\hline
\end{tabular}

Dari tabel 3 diperoleh data untuk kelas eksperimen persentase jawaban benarnya untuk pretes 19,44 \% dan postesnya sebesar $70 \%$ sehingga peningkatannya sebesar 50,56 \%. Sedangkan untuk kelas konvensional nilai pretesnya 19.63 dan postesnya 59,63 sehingga peningkatannya sebesar $40 \%$. Dengan simpangan baku untuk kelas eksperimen untuk pretes 9.64 dan postes 11.18. Sedangkan kelas kontrol hasil simpangan baku pretes 9.19 dan postes 12.85

Selanjutnya untuk melihat perbedaan secara signifikan dari kedua kelas tersebut di gunakan uji t karena kedua kelompok berdistribusi normal serta homogen. Dari hasil uji $t$ berbantuan SPSS diperoleh Independent Samples Test, sig =0,003 < 0,05 artinya ada perbedaan kemampuan akhir antara mahasiswa kelas eksperimen dengan Mahasiswa kelas kontrol. Untuk 
gain ternormalisasi terdapat pada Gambar 1 berikut.

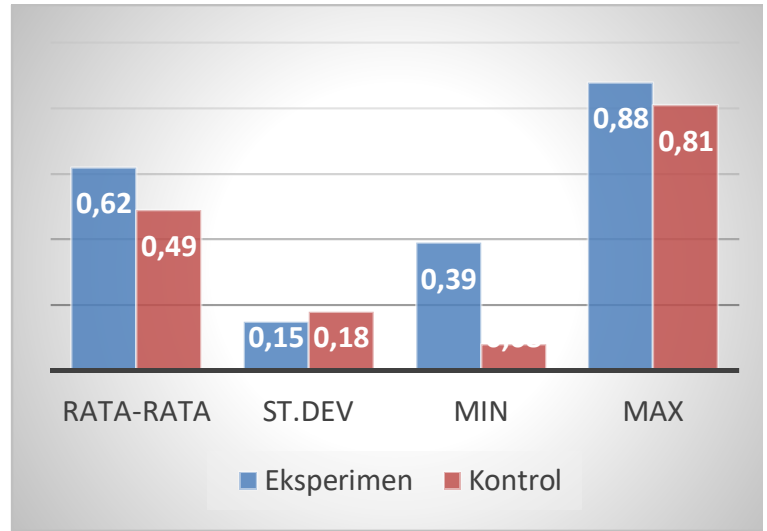

Gambar 1. Hasil gain ternormalisasi kemampaun koneksi matematik
Dari hasil gambar 1 menunjukkan kelas eksperimen mendapat rataan hitung sebesar 0.62 dan simpangan baku 0.15 ,sedangkan kelas kontrol mendapat rataan hitung sebesar 0.49 serta simpangan baku 0.18. Dari hasil tersebut ditinjau dari nilai rataan hitung gain ternormalisasi keduanya berada dalam tingkatan sedang, namun kelas eksperimen lebih besar 0.13 daripada kelas kontrol.

Oleh sebab itu untuk melihat perbedaan yang signifikan atau peningkatan mana yang lebih baik dilanjutan dengan uji $\mathrm{t}$ dengan SPSS, hasilnya terdapat pada tabel 5 .

Tabel 5

Uji t Kemampuan Koneksi Matematik

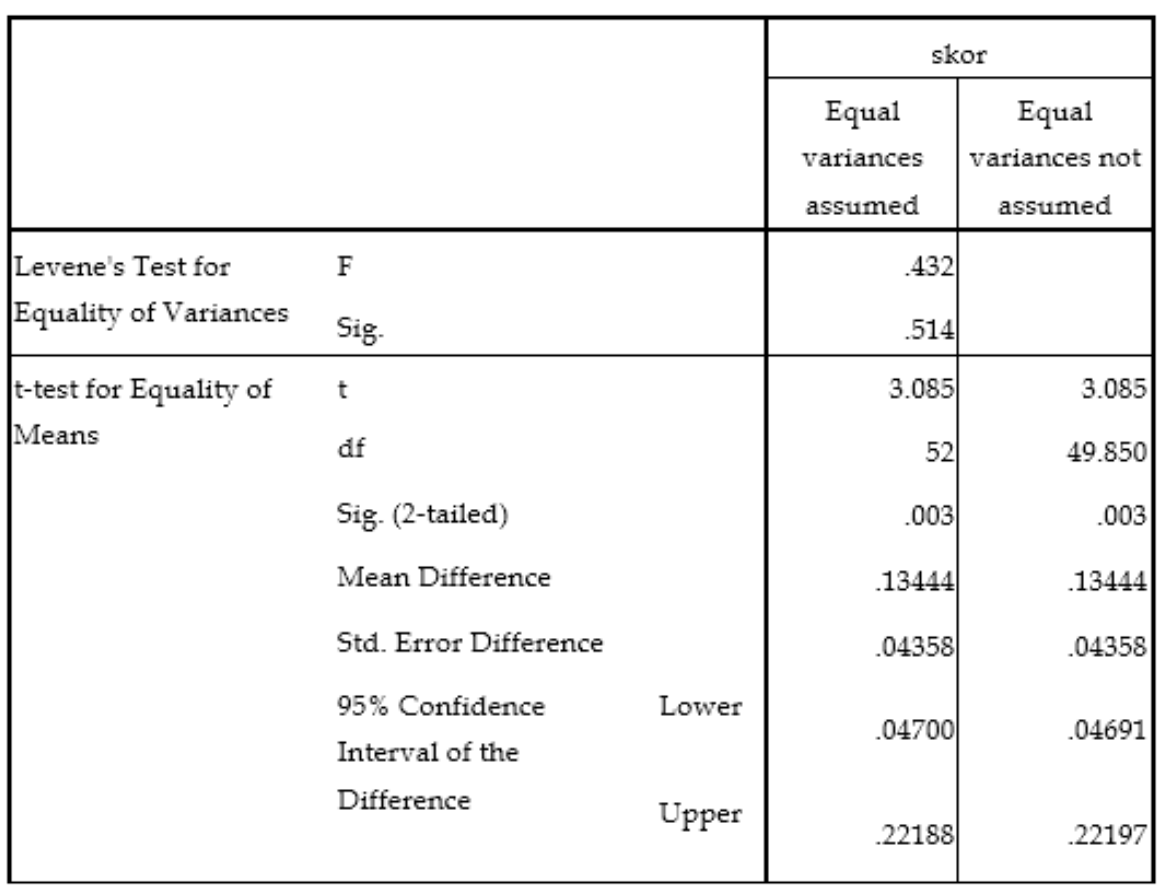

Pada tabel 5, menunjukkan hasil Sig. (2tailed) < 0,05 artinya Ha yang diterima dapat dikatakan peningkatan kemampuan koneksi matematik kelas eksperimen lebih baik daripada kelas kontrol.

Pada kelas eksperimen yang mendapat perlakuan dengan model CORE terjadi peningkatan karena dalam model CORE terdapat empat tahapan yaitu Connecting, Organizing, Reflecting dan Extending (CORE) dimana adalah Connecting (C) pada tahapan ini mahasiswa diingatkan kembali mengenai materi yang telah dipelajari mengenai turunan dan integral yang Mosharafa: Jurnal Pendidikan Matematika Volume 9, Nomor 3, September 2020 Copyright $\odot 2020$ Mosharafa: Jurnal Pendidikan Matematika 
merupakan syarat mempelajari persamaan diferensial, pada tahap Organizing (O) mahasiswa diberikan lembar kerja mahasiswa mengenai materi persamaan diferensial misalnya pada topik persamaan diferensial biasa (PDB) orde satu linier dengan bimbingan dosen mereka memahami materi tersebut. selanjutnya pada tahap Reflecting ( $R$ ) mereka memikirkan kembali konsep dengan menyelesaikan persoalan PDB orde satu linier secara berkelompok dan membahas solusi dari permasalahan tersebut, terakhir Extending (E) pada tahapan ini mahasiswa diberikan lagi permasalahan berupa quis dan pemberian tugas, selain itu dosen menginformasikan bahwa materi PDB orde satu linier merupakan konsep yang berkaitan dengan Rangkaian Listrik.

Dengan pembelajaran model CORE mahasiswa berlatih berfikir mandiri dalam menghubungkan antar konsep matematika baik dalam matematika itu sendiri maupun diluar bidang matematika. Sejalan dengan itu, menurut Humaira (2014) model CORE pada pembelajaran membuat siswa aktif dalam membangun pengetahuannya

Sejalan dengan hasil penelitian ini, dari Beladina (2013) yang melakukan penelitian di SMP Negeri 2 Semarang yang pada kesimpulannya bahwa kreativitas matematis siswa yang mengikuti model pembelajaran kooperatif tipe CORE lebih baik dari kreativitas matematis siswa yang mengikuti pembelajaran konvensional.

Selanjutnya untuk hasil dari Self efficacy tersaji dalam tabel 6. Kemudian dilakukan uji t dengan hasil perhitungannya terdapat pada tabel 7 .

Tabel 6.

Rekapitulasi Hasil Angket Self Efficacy

\begin{tabular}{|c|c|c|c|}
\hline & & \multicolumn{2}{|c|}{ Kelas } \\
\hline \multirow{2}{*}{$\begin{array}{l}\text { Skor } \\
\text { ideal }\end{array}$} & & eksperimen & Kontrol \\
\hline & $\mathrm{N}$ & \multicolumn{2}{|c|}{27} \\
\hline \multirow{5}{*}{48} & $\bar{X}$ & 36,27 & 35,19 \\
\hline & $\%$ & 75,57 & 73.31 \\
\hline & St.dv & 3.06 & 3.09 \\
\hline & $\min$ & 30 & 29 \\
\hline & Max & 42 & 40 \\
\hline
\end{tabular}


Tabel 7.

Uji t Skor Self efficacy Mahasiswa

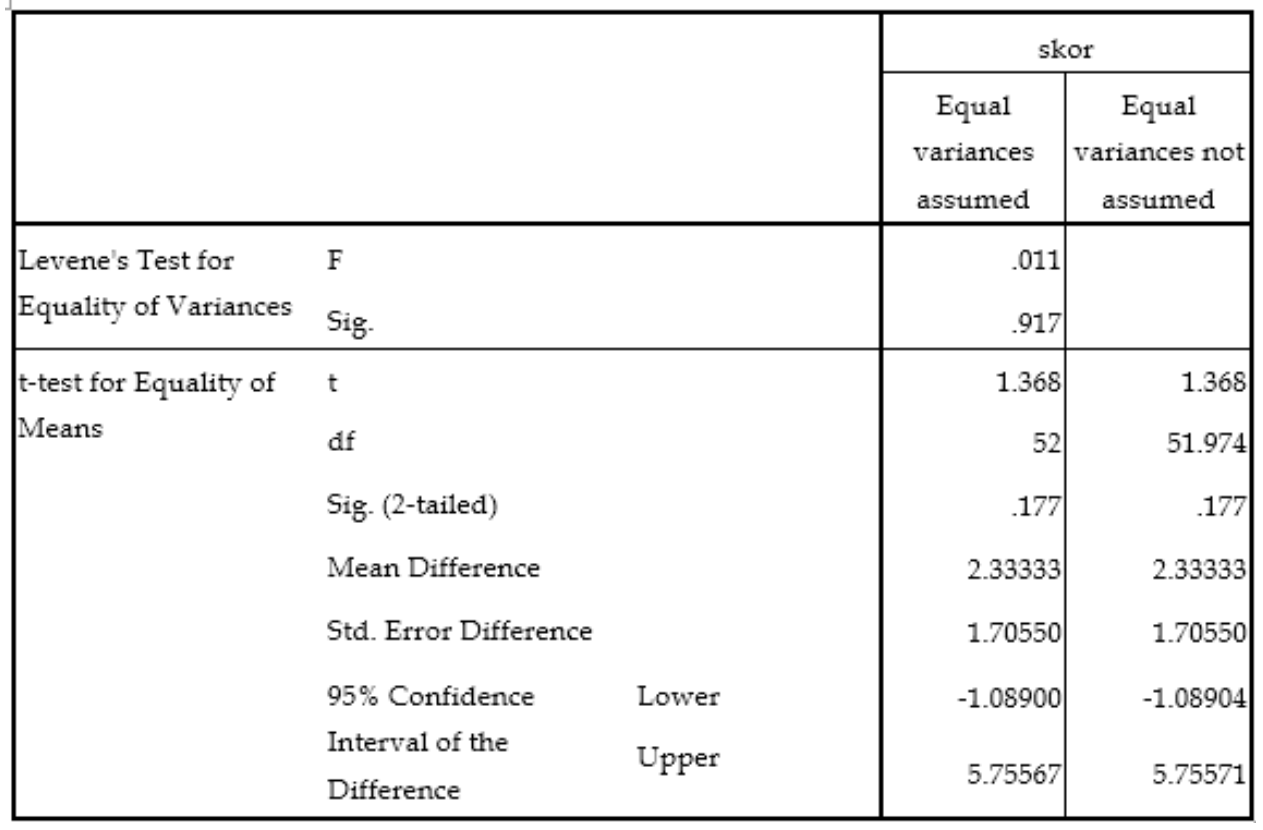

Dari tabel 7 hasil uji t, diperoleh nilai signifikansi sebesar 0,177. Untuk memperoleh hasil digunakan uji satu pihak dengan membagi dua nilai signya (Uyanto, 2009). Maka didapat nilai sig 0,089 $>\alpha(\alpha=$ $5 \%$ dapat disimpulkan secara signifikan peningkatan self efficacy kelas eksperimen tidak lebih baik dari kelas kontrol.

Berdasarkan hasil kesimpulan dari tabel.7 yang menyatakan bahwa model CORE tidak berpengaruh secara signifikan terhadap peningkatan Self efficacy mahasiswa, ini terjadi dikarenakan dari hasil angket pada pertanyaan "Saya yakin dapat menyelesaikan masalah matematika yang diberikan dosen walapun rumit" ratarata mahasiswa menjawab TS (Tidak Setuju), ini mengindikasikan bahwa mereka kurang yakin bila mendapatkan soal yang lebih rumit dari yang biasa mereka dapatkan selama pembelajaran walaupun dari pandangan peneliti mereka bisa mengerjakannya. Sebab dalam keyakinan matematika menurut Sugiman 436
(2009), ada tiga aspek yang secara simultan berpengaruh terhadap keyakinan matematik, yaitu objek pendidikan matematika, konteks kelas, dan dirinya sendiri.

Dengan menggunakan uji spearman berbantuan SPSS didapat hasil berikut ini : Dari data tabel 6 . didapat nilai sig 0,01< 0,05 maka didapat kesimpulan terdapat hubungan antara kemampuan koneksi matematik dengan self efficacy begitu juga jika ditinjau dari $r$ hitung didapat 0,486 >r tabel 0.381 maka menunjukkan ada hubungan dari keduanya dengan nilai 0,486 yang termasuk dalam kategori Cukup. Dari hasil ini memberikan gambaran jika keyakinan diri mahasiswa baik maka akan berdampak pada peningkatan kemampuan koneksi matematik begitupun sebaliknya jika keyakinan diri mahasiswa kurang maka kemampuan koneksi matematik akan kurang juga.

Pada penelitian ini juga dikaji mengenai Sikap atau tanggapan mahasiswa terhadap Mosharafa: Jumal Pendidikan Matematika Volume 9, Nomor 3, September 2020 Copyright $\odot 2020$ Mosharafa: Jurnal Pendidikan Matematika 
model CORE dan self efficacy yang didapat dari hasilnya angket. Dari hasil perhitungan didapat persentase respon mahasiswa terhadap model CORE 76,54\% dalam kategori kuat, sedangkan terhadap Self efficacy sebesar 75,57 \% (dalam kategori kuat) dari hasil tersebut tidak heran karena selama pengamatan pada saat pembelajaran berlangsung terlihat mahasiswa aktif berdiskusi di dalam kelompoknya pada usaha dalam memahai, menyelesaikan, dan menganalisis persoalan yang diberikan oleh dosen. Dengan demikian pembelajaran jadi tidak satu arah dan tidak kaku sehingga mereka tidak jenuh selama pembelajaran berlangsung.

\section{Penutup}

Peningkatan Kemampuan koneksi matematik mahasiswa yang mendapatkan pembelajaran dengan model CORE lebih baik dari pada mahasiswa yang memperoleh pembelajaran konvensional. Sedangkan pada peningkatan self efficacy matematik, mahasiswa yang mendapatkan pembelajaran model CORE tidak lebih baik dari pada mahasiswa yang memperoleh pembelajaran konvensional. Keterkaitan antara koneksi matematik dan self efficcacy, dari hasil perhitungan berada di kategori sedang. Terakhir untuk hasil analisis angket mendeskripsikan bahwa mahasiswa memberikan respon yang positif terhadap model CORE.

\section{DAFTAR PUSTAKA}

Afriansyah, E. A. (2012). Design Research: Konsep Nilai Tempat pada Penjumlahan Bilangan Desimal (Doctoral dissertation, Tesis yang tidak dipublikasikan berasal dari Beasiswa DIKTI dengan program IMPoME (International Master Program on Mathematics Education). Universitas Sriwijaya Palembang-Universitas UTRECHT Belanda).

Alexandra, G., \& Ratu, N. (2018). Profil kemampuan berpikir kritis matematis siswa SMP dengan graded response models. Mosharafa: Jurnal Pendidikan Matematika, 7(1), 103-112.

Asih, N., \& Ramdhani, S. (2019). Peningkatan Kemampuan Pemecahan Masalah Matematis dan Kemandirian Belajar Siswa Menggunakan Model Pembelajaran Means End Analysis. Mosharafa: Jurnal Pendidikan Matematika, 8(3), 435-446.

Beladina, N. (2013). Keefektifan Model Pembelajaran CORE Berbantuan LKPD terhadap Kreativitas Matematis Siswa. Unnes Journal of Mathematics Education, 1(1).

Bandura, A (1997). Self Efficacy The Excercise of Control. USA: W. H Freeman and Company.

Dewi, S. S. S., \& Afriansyah, E. A. (2018). Kemampuan Komunikasi Matematis Siswa Melalui Pembelajaran CTL. JIPMat, 3(2), 145-155.

Humaira, F. A., dkk. (2014). Penerapan Model Pembelajaran CORE pada Pembelajaran Matematika Siswa Kelas X SMAN 9 Padang. Padang. Jurnal Pendidikan Matematika, 3(1). 31-37.

Hiebert, J., \& Carpenter. (1992). Learning and teaching with Understanding, in $D$. A. Grouws (Ed.), Handbook of Research on Mathematics Teaching and Learning. (New York: Macmillan Publishing Company, 1992) $65-97$.

Lubis, R., Harahap, T., \& Nasution, D. P. (2019). Pendekatan Open-Ended dalam 
Membelajarkan Kemampuan Koneksi Matematis Siswa. Mosharafa: Jurnal Pendidikan Matematika, 8(3), 399-410. Mayasari, Y., \& Afriansyah, E. A. (2016). Kemampuan Koneksi Matematis Siswa melalui Model Pembelajaran Berbasis Masalah (Studi Penelitian di SMP Negeri 5 Garut). Jurnal Riset Pendidikan, 2(01), 27-44.

Moma, L. (2014). Self-efficacy matematik pada siswa SMP. Mosharafa: Jurnal Pendidikan Matematika, 3(2), 85-94.

Mujib, A. (2017). Identifikasi Miskonsepsi Mahasiswa Menggunakan CRI pada Mata Kuliah Kalkulus II. Mosharafa: Jurnal Pendidikan Matematika, 6(2), 181-192.

National Council of Teachers of Mathematics. (2000). Principles and Standarts for School Mathematics. Reston, VA: NCTM.

Ngalimun (2014). Strategi dan Model Pembelajaran. Aswaja pressindo. Yogyakarta.

Nur Fallah, A. (2017). Pengaruh Model Core (Connecting, Organizing, Reflecting, Dan Extending) Terhadap Peningkatan Kemampuan Koneksi Matematis Dan Self-Efficacy Siswa Sma. Skripsi. Unpas Bandung: Tidak Diterbitkan.

Pitriani, R., \& Afriansyah, E. A. (2016). Persepsi dalam pembelajaran pendekatan keterampilan proses terhadap kemampuan koneksi matematis siswa (Studi penelitian di SMP Negeri 1 Wanaraja). Jurnal Gantang, 1(2), 15-24.

Robbins, S. P. (2003). Perilaku Organisasi Jilid 1. Jakarta: Indeks Kelompok Gramedia.

Ruseffendi, E. T. (2010). Dasar-Dasar Penelitian Pendidikan dan Bidang Non-
Eksakta Lainnya (Edisi Cetak pertama). Bandung: Tarsito.

Sapilin, S., Adisantoso, P., \& Taufik, M. (2019). Peningkatan Pemahaman Konsep Peserta Didik dengan Model Discovery Learning pada Materi Fungsi Invers. Mosharafa: Jurnal Pendidikan Matematika, 8(2), 285-296.

Sugiman. (2009). Aspek Keyakinan Matematik Siswa dalam Pendidikan Matematika. Tersedia online: http://staff.uny.ac.id/sites/default/files/ 131930135/2009b_KYM_0.pdf di akses [19-07-2019]

Uyanto, S. S. (2009). Pedoman Analisis Data dengan SPSS. Yogyakarta: Graha IImu.

\section{Riwayat Hidup Penulis \\ Tri Arif Wiharso, M.Pd}

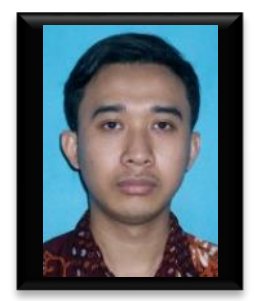

Lahir di Garut, 13 Mei 1986. Staf pengajar di fakultas teknik Universitas Garut. Studi S1 Pendidikan Matematika STKIP garut, lulus tahun 2009; S2 pendidikan Matematika Universitas Pasundan

Bandung, lulus tahun 2014;

\section{Helvy Susilawati, S.Pd, M.T.}

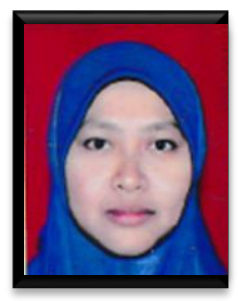

Lahir di Sumedang, 1 Desember 1989. Staf pengajar di fakultas teknik Universitas Garut. Studi S1 Pendidikan Fisika, UIN Sunan Gunung Djati, lulus tahun 2011; S2 Teknik elektro Institut Teknologi Bandung, lulus tahun 2014; 